\title{
Assessment of Medical Waste Management in Health Centers of Maroua-Cameroon
}

\author{
Cornelius Tsamo ${ }^{1 *}$, Arbam Tsafam ${ }^{2}$ and Poliance Dougoua Djiantio ${ }^{2}$ \\ ${ }^{1}$ Department of Chemistry, Higher Teachers' Training College, Universty of Maroua, P.O. Box 55 Maroua, \\ Cameroon \\ ${ }^{2}$ Department of Chemistry, Faculty of Science, Universty of Maroua, P.O. Box 46 Maroua, Cameroon
}

\begin{abstract}
Medical waste unlike other ordinary waste does not only poses serious health risk to the handlers, health staff andpatients but also to the environment. Waste management in general and particularly medical waste from health carefacilities is highly neglected in developing countries due to lack of trained personnel and lack of funds to adopt appropriate waste management technologies. In Cameroon, there is very little data available on the management of medical waste. This motivated this paper whose objective was to assess the medical waste managementpractices in health centers (public and private) in Maroua. The study used structured questionnaires, observation checklist and key informant interview guide to collect data fromall health personnel in health centers, local councils and decentralized government services in charge of hospitals and waste management respectively. It was observed that the number of health centers authorized by government is less than those actually operating in the field. Also managers of most health centers have designated some of their personnel or created commissions to manage waste. But nearly all of them have very little knowledge on medical waste management procedures as they are mainly trained by managers of their structures rather than experts. Generally medical waste management practices such as sorting, segregation, collection; treatment and disposal were very rudimentary and obeyed no standard rules. There is no control on medical waste management practices in health centers by different stake holders concerned because no legislation compels them to do so. This study has shown that, waste management in the health centers in Maroua respects no norms and thus, can have serious health implications to the handlers, staff, patients and visitors; this stemming from poor legislation and regulatory systems.
\end{abstract}

Keywords:Medical Waste, Maroua, Health centers waste Management, Developing Countries, Public and Private Health Centers

\section{Introduction}

The protection of the environment has become a collective concern of date because issues of waste management affect our daily life's both at professional and family levels. Indeed, the world is generating more and more waste; hospitals and health centers are no exception. Medical waste is an issue of growing concern since it is a source for contamination and pollution, capable of causing diseases and illness either through direct contact or indirectly by contamination of soil, ground water, surface water and air as health care establishments are an integral part of the life support system (El Mabrouk, 2014). Healthcare waste contains infectious pathogens, toxic chemicals and heavy metals and may contain substances that are genotoxic or radioactive (Mmereki et al. 2017). When hazardous health care wastes are not properly managed, exposure to them could lead to infections, infertility, genital deformities, hormonally triggered cancers, mutagenicity, dermatitis, asthma and neurological disorders in children; typhoid, cholera, hepatitis, AIDS and other viral infections through sharps contaminated with blood (Oli et al. 2016). For example, WHO estimated that, in 2000, injections with contaminated syringes caused 21 million hepatitis B, 2 million hepatitis C and 260,000 HIV infections (WHO, 2005a). The people at risk of healthcare hazardous waste include healthcare workers, patients, visitors to healthcare establishments, workers in support services, workers in waste disposal facilities, fetuses in the wombs of mothers, members of public and scavengers(Oli et al. 2016).Table 1 illustrates some examples of infection that can be caused by exposure to health-care waste, and usual ways of transmission vehicles (Nascimento Silva et al. 2013; WHO, 1999). 
Table 1: Examples of infections caused by exposure to health-care wastes, causative organisms, and transmission vehicles

\begin{tabular}{|c|c|c|}
\hline Type of Infecction & Examples of causative organisms & Transmission vehicles \\
\hline \multicolumn{3}{|c|}{ Bacteria } \\
\hline Gastroenteric Infections & Salmonella typhi & Feces and or Vomit \\
\hline Gastroenteric Infections & Shigella SP & Feces and or Vomit \\
\hline Bacteremia & Enterobacter & Blood \\
\hline Bacteremia & Klebsiella & Blood \\
\hline Skin Infections & Streptococcus SP & Secretion \\
\hline Bacteremia & Staphylococcus aureus & Blood \\
\hline Respiratory Infections & Mycobacteriumtuberculosis & Secretionsinhaled, Spittle \\
\hline $\begin{array}{l}\text { Acquiredimmunodeficiency syndrome } \\
\text { (AIDS) }\end{array}$ & Humanimmunodeficiency virus (HIV) & Blood, sexualsecretions \\
\hline Meningitis & Neisseriameningitidis & Cerebrospinalfluid \\
\hline Anthrax & Bacillus anthracis & Skin secretions \\
\hline \multicolumn{3}{|c|}{$\begin{array}{r}\text { VIRUS } \\
\end{array}$} \\
\hline Inflammation of the liver & Hepatitis A & Feces \\
\hline Inflammation of the liver & Hepatitis B & Blood and Body fluids \\
\hline Inflammation of the liver & Hepatitis C & Blood and Body fluids \\
\hline \multicolumn{3}{|c|}{ Fungi } \\
\hline Candidemia & Candida albicans & Blood \\
\hline
\end{tabular}

World Health Organization (WHO) defined medical waste as any waste which consists wholly or partly of human or animal tissue, blood or other bodily fluids, excretions, drugs or other pharmaceutical products, swabs or dressings, needles or other sharps; and any other waste arising from medical, nursing, dental, veterinary, pharmaceutical or similar practice, investigation, treatment, care, teaching or research, or the collection of blood for transfusion (Tiong et al. 2012). A World Health Organization (WHO) report states that 75-90\% of hospital waste is non-risk or general" waste, comparable to municipal solid waste (MSW). The remaining 10-25\% of hospital waste is regarded as infectious and hazardous and may pose a variety of health risks. If both these types are mixed together then the entire quantity becomes contaminated and harmful (Mmereki et al. 2017). Though there is a greater recognition worldwide today that health centers waste should be managed properly (Mmereki et al. 2017; Hadipouret al. 2014; Shineeet al. 2008), several studies in Africa pointed out that healthcare waste management is still in its infancy; characterized by the lack of awareness on the impacts of healthcare waste, the total absence of medical waste regulations and a high incidence of noncompliance in cases where they exist (Mmereki et al. 2017). This despite the fact that during the past decade, large amounts of diverse healthcare risk waste discarded by health care facilities (HCFs) have been rapidly piling up in emerging economies (Mmereki et al. 2017; WHO, 2008) due to increase in population accompanied with different health needs. This is in contrast to developed countries, where legislation and good practice guidelines define medical wastes and state the various possible mays for collection, transport, storage and disposal of such wastes (Tudor et al. 2005). Because medical waste management is an important public health concern; one of the first critical steps in the process of developing a reliable waste management plan requires a comprehensive understanding of the qualification of those handling the waste, types of the wastes and the existing management practices.

In Cameroon, little or no data is available concerning generation, handling and disposal of medical waste.This study is aimed at identifying the different health centres in Maroua, evaluate hospital personnel awareness on medical waste, identify the different types of waste generated, observe the processes for waste collection, treatment and disposal and investigate the existence of any legislation on medical waste management in Cameroon.

\section{Study area}

Maroua is a town located in northern Cameroon at $10^{\circ} 64^{\prime}$ north latitude and $14^{\circ} 27^{\prime}$ east longitude. The dry season lasts 7 months, from October to April and the average annual rainfall is around 700 to $800 \mathrm{~mm}$ per year. The average annual temperature is $28{ }^{\circ} \mathrm{C}$. Its population has increased from 386569 inhabitants in 1987 to 642227 inhabitants in 2005 with a population density of 137.7 inhabitants $/ \mathrm{km}^{2}$ (INS, 2015). Maroua covers a surface area of $4665 \mathrm{~km}^{2}$. Due to the high increase in the population, the government of Cameroon in 2008 divided the city of Maroua in to three council areas (Maroua I, Maroua II, and Maroua III) for better decentralized management of the city. Each of these councils is supposed to benefit from a certain number of public health units as installation of private health units is dependent on the operator.

Maroua is the transit town to other towns of the CEMAC notably Tchad, and has a long border with Nigeria. There is a very strong cultural links between these countries and Cameroon. As such movement in search for different services, particularly to Maroua for health needs is routine. The Sudano-Sahelian climate of Maroua also leads to the occurrence of different epidemics resulting from climatic variations thus, congesting 
the few ill-equipped health units available. Thus, continuously increasing population of Maroua, its transit and touristic character and variability in is climate will continue to put pressure on its few health structures. So, the need for good practices in management of waste in these health units to avoid further health and environmental hazards linked to poor management of medical waste. This study was conducted in both public and private health centres and clinics spanning the three council areas of Maroua as shown in figure 1. They are mostly located in the periphery of the town and highly used by the less privilege social group due to economic factors. Most of those working there are nurses who may not have adequate knowledge on certain good practices such as better management of the medical waste they generate to their patients and the environment.

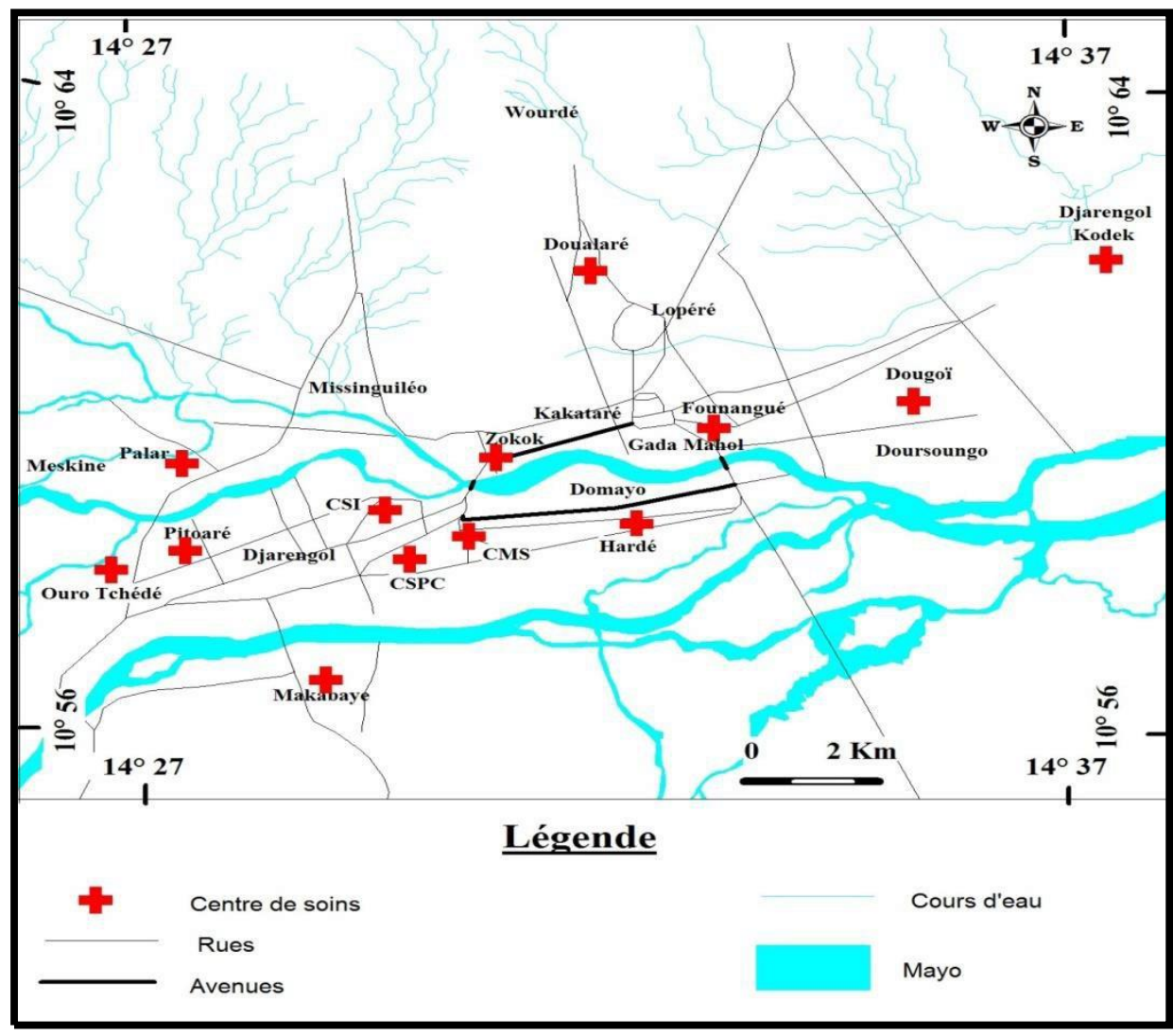

Source: Field studies

Figure 1: Geographical location of the different health centres surveyed in Maroua

\section{Materials and Method}

\subsection{Survey methods}

A number of survey techniques were used to collect data for the study. These are summarized as follows:

$>\mathrm{A}$ visit was made to the decentralized government structure (regional delegation of public health) responsible for health services. This was firstly aimed at getting the number of health centres and clinics that exist in Maroua and secondly, their role in enforcing good waste management practices in these structures.

$>$ A field study was then made to identify and corroborate the list of health centers and clinics given by the regional delegation of public health. Interviews were used to collect data on waste practices associated with storage, collection, treatment and disposal of healthcare waste from supervisors, sanitation workers and nurses who are directly responsible for handling of various waste streams at individual facilities. The questionnaires were designed to obtain information on training, sorting and storage, collection, treatment and disposal of generated health centers waste. The results were used to establish the operation of the healthcare waste management system.

$>$ In each of the health centers investigated, site visits, including transient walkthrough inspections were undertaken across the entire facility to identify the waste collection, handling and disposal practices at the facility. Images of some of these practices were taken.

$>$ With questionnaires, we visited the local councils and a private waste management company in Maroua, HYSACAM for their roles in medical waste management in Maroua. We also visited the regional delegation of the ministry of environment, Maroua (responsible for conceiving and enforcing waste 
management legislation in Cameroon) to find out if there exist any legislation in Cameroon on medical waste management.

$>$ Review of related reports and previous research reports from scientific articles was undertaken. The available literature was reviewed to allow comparisons to be made on storage, collection, treatment and disposal of healthcare waste in other countries.

Informed consent was obtained from those selected for interviews. Before data collection, the researchers described the goals and methods to those selected for interviews. This was necessary as most of the interviewers were afraid of subsequent punitive measures and increase fiscal measures on operators of private health units.

\subsection{The different health centres identified}

\section{Results and Discussion}

Seventeen health centres were identified with public owned centers dominating. In Maroua I council area there were five public health centres; one created in 1987, one in 2002, one in 2004 and two in 2006. The three private health centres were created in 1995, 2002 and 2006. In Maroua II, one public health centre was created in 1954, one in 1967 and two in 2006. This council area has only one private health centre. Only one public health centre created in 1985 exists in Maroua III, the three others created from 1980 to 2011 are all private. This trend in the creation of health centres indicates the growth (particularly population increased) of the city and the Cameroon government's desire to take health facilities closer to the population. Most of these centres are not meant to handle complicated health situations and thus are not sufficiently equipped in equipment, adequate and qualified personnel. This is the principal reason why they seem to be many in number. This study revealed significant discrepancy between the number of health centres authorized and those we actually identified on the field. While all the public centres identified were corroborated with the list obtained at the delegation of public health, this was not the case with the private centres. This is a possible source for bad medical waste management practices as most of these non-authorized structures are not being controlled by authorized body.

\subsection{Service responsible for waste management}

Investigation on whether there are services in charge of waste management revealed that $61.5 \%$ of the health centres have personnel responsible for waste management and $38.5 \%$ do not have. Out of the $61.5 \%$ of the health centres that have personnel responsible for waste management only $38.5 \%$ has been trained $(50 \%$ being health care assistants, $37.5 \%$ being registered nurses and $12.5 \%$ being maintenance agents). $38.5 \%$ of health centres with no personnel for waste management and same percentage trained for waste management where these personnel exist is a cause for concern owing to the delicacy of medical waste. Blood, other fluids, syringes, faeces etc. not well disposed can caused many diseases as shown in Table 1. This is even more alarming as most of those who visit these health centres have no knowledge on the risk of being infected with different medical waste they encounter.

\subsection{Classifications and types of waste}

Our survey on the types of waste generated was carried out in the maternity, pharmacy, laboratory, curative and prenatal consultation and immunization services within these health centers. To this end, four groups of hospital waste were identified: Liquid organic waste that was mainly blood and secretions; solid waste that included paper, cardboard, placentas, cotton and compresses; plastic waste such as packaging, syringes and gloves and sharp objects such as needles, blades and clamps. None of the surveyed health centers kept records on the quantities of waste generated. The waste composition and characteristics was similar with the general classification of the waste generated at the health centers (Table 2), and particularly in developing countries (Mato and Kassenga, 1999).

Table 2: Classification of the different types of healthcare waste (Mmereki et al. 2017)

\begin{tabular}{|l|l|}
\hline Types of waste & Composition \\
\hline General & $\begin{array}{l}\text { Packaging materials (mostly cardboard), office paper, food remains, } \\
\text { cans, plastic bags } \\
\text { and containers, etc. }\end{array}$ \\
\hline Health care (infection) & $\begin{array}{l}\text { Clinical specimen, culture plates, drainage bags, surgical waste, } \\
\text { autopsy waste, blood, blood products and body fluids }\end{array}$ \\
\hline Health care (pathological & $\begin{array}{l}\text { Human tissues, organs, foetuses, placentas, amputated body parts } \\
\text { and other body parts }\end{array}$ \\
\hline Health care (solid chemicals and pharmaceutical waste) & Spilled or expired drugs and chemicals \\
\hline Sharps & Needles, syringes, broken glasses, scalpels, etc \\
\hline
\end{tabular}


The classification of the waste by the health centers was taken so as to compare with international practices. Unfortunately there is no classification from the national government, as there are no regulations on healthcare waste but only guidelines on general waste management.

\subsection{Waste sorting and storage}

This involves a clear identification of the different categories of waste and means of separating them. Our survey showed that waste sorting is carried out at the level of each service where they disposed their wastes into specific waste bins. For example, sharps and sharp cutting objects are placed in safety boxes as shown in figure 2, soft solid wastes such as cottons are placed in garbage bins (figure 3) and plastic waste (gloves, syringes) are disposed into trash bins (figure 4). Liquid wastes (secretion etc.) form different wards are dumped into septic tanks commonly known as organic waste pits (figure 5). The contents of these pits are never evacuated or treated. These pits were absent in some health facilities where liquid waste is disposed in open air. This has been the probable mode of transmission of bacterial causing diseases like cholera in Maroua with 601 deaths out of 9404 detected cholera cases in 2010 (Djao R. et al., 2011; WHO, 2011). Efficient sorting of healthcare waste by healthcare centre facilities helps to prevent and minimize the mixing of hazardous waste with general waste, which may lead to the waste stream being infected or contaminated (Mmereki et al. 2017, Sabour et al. 2007).

Although the sorting of different waste was respected, all the containers used (except safety box) did not obey any standard and all did not exhibit any universal biohazard sign that is commonly used in many countries. This is very dangerous as it may result in cotton contaminated with infected blood or contaminated injection equipment being scavenged and reused. More to this, is the fact that all the waste collected at the level of different services or wards stay there for an average of 6 to 24 hours before being evacuated to disposal sites. $77 \%$ of the health centers respect this operation and $23 \%$ do not where sorted waste can spend up to three days before evacuation. However, in most missionary owned health centers, hygiene and sanitation was highly implemented and waste evacuation is after every one to two hours.

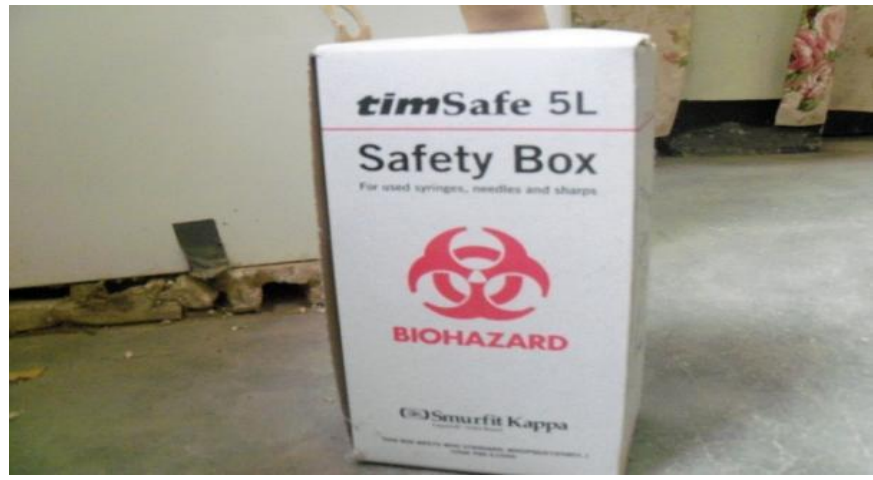

Figure 2: Safety box for collection of sharp objects

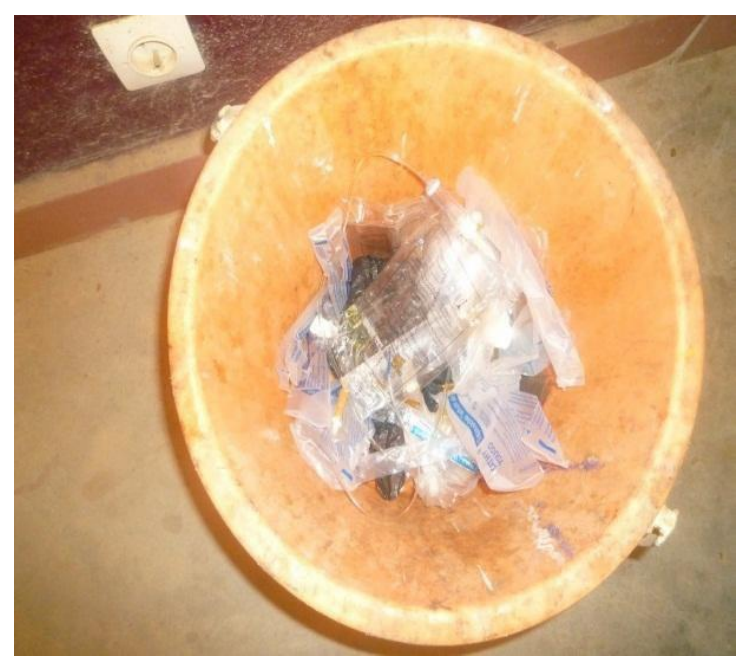

Figure 4: Garbage bin for soft plastic waste 


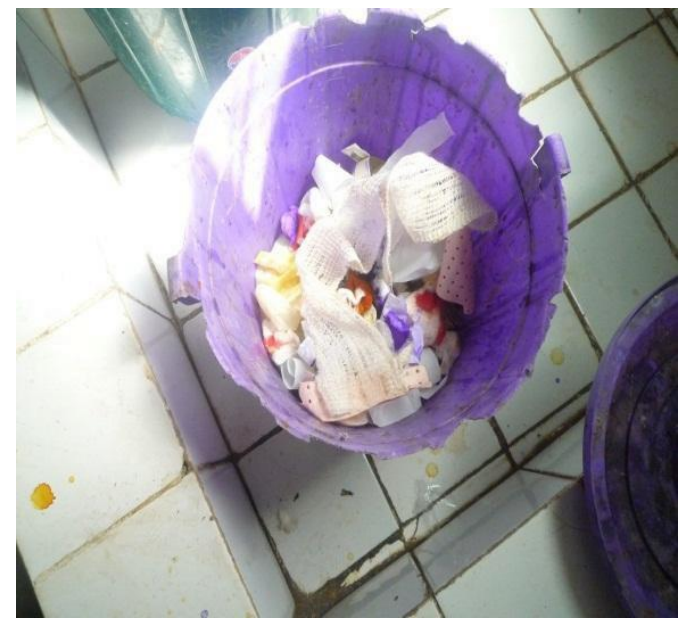

Figure 3: Garbage bin for soft solid waste

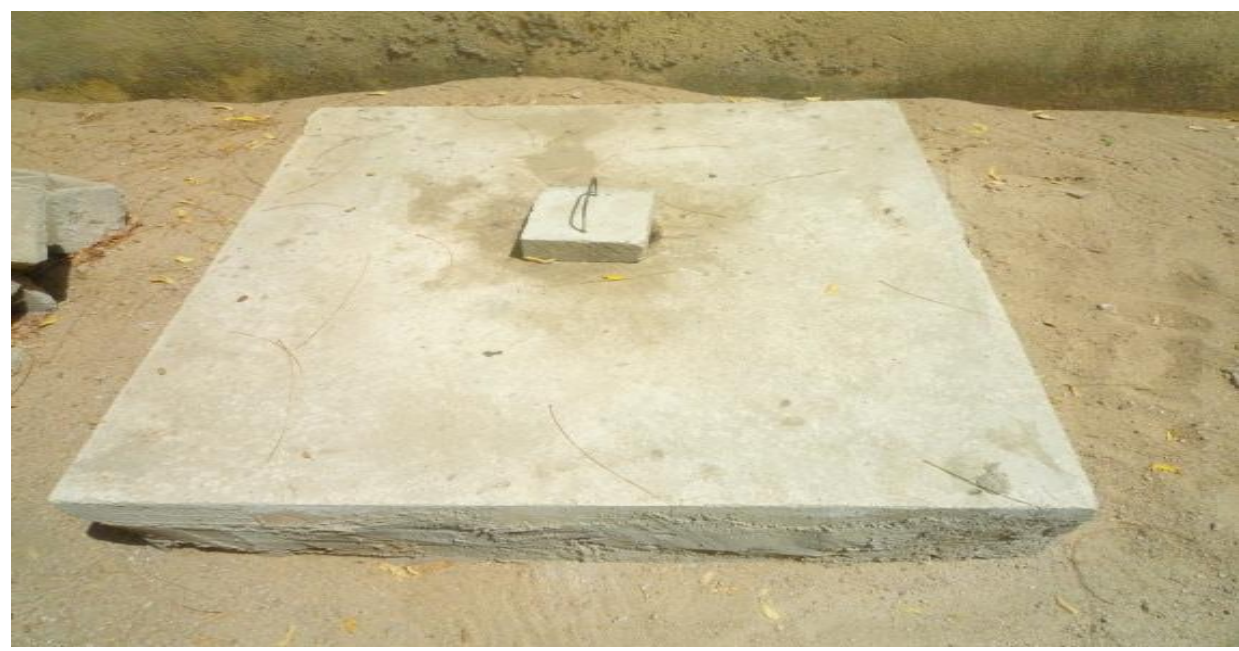

Figure 5: Septic tank

\subsection{Waste collection and segregation}

Solid wastes generated at all the health centers were collected by those responsible for Management of this waste, maintenance agents or by the special Commissions set up (mostly in mission own health centers) and employees in each department using bins (figure 2, 3 and 4). Unfortunately, there are no developed national guidelines on the management of this healthcare waste in Cameroon. It was also noticed that there are no private operators specialized in the collection of hospital waste in Maroua. Worse of all, there are no designated sites for the storage of this waste. Colour is used to differentiate containers for storing various types of healthcare waste at the generation point as shown if Table 3 (Mmereki et al. 2017; Mbongwe et al. 2008). Figures 2-4 shows that this is not practiced in the health centers of Maroua. As a result, the individual waste types and categories were routinely not segregated prior to final disposal. Infectious, pathological and chemical wastes were all collected in same bin bags (figures 3 and 4) just because they fall in same category (although their disposal methods are different). These practices were common in all the structures surveyed.

Table 3: Showing the types of containers used to collect different types of hospital solid waste

\begin{tabular}{|l|l|l|l|}
\hline Types of waste & Container & Colourused by hospitals & Recommendedcolours \\
\hline General & Plastic bag in bin container & Black/red plastic bag & Black plastic bag \\
\hline $\begin{array}{l}\text { Solid chemicals and } \\
\text { pharmaceutical waste }\end{array}$ & Plastic bag in bin container & Red plastic bag & Brown plastic bags or container \\
\hline Clinical and infectious & Plastic bag in bin container & Red plastic bag & Yellow plastic bags/container \\
\hline Pathological & Plastic bag in bin container & Red plastic bag & Yellow plastic bags/container \\
\hline Sharps & Bin beez & Yellow bin beez & Yellow bin beez \\
\hline
\end{tabular}




\subsection{Waste transportation}

After the collection of these wastes, they are transported manually by the personnel designated for the management of wastes within the health centerconcerned to treatment or disposal areas.In all facilities surveyed, waste bins were emptied at least once a day, typically in the morning. All bins (except secretions, disposed immediately) containing other waste were disposed between 6 to 24 hours in public and private health centres and every one to two hours in mission owned health centers. Secretions were not allowed to accumulate due their odour and to avoid flies which are vectors of further transmission of diseases. Those transporting these wastes did so without any personal protective clothing and equipment. Generally, this exposes the workers to high occupational and health hazards (Mmereki et al. 2017; Mato et al. 1999). Wastes were manually transported (e.g. in metal bins and plastic bags) to the waste disposal/temporary storage sites with the use of trolleys or push trucks. This practice could lead to the leakage or spillage of waste content along the transport route, exposing workers, patients and the public to the risks of injury and health. Therefore, recommended procedures for cleaning of spills should be applied (Mmereki et al. 2017; Oke, 2008). Most of those handling waste issues in these health centres were simply appointed (for service reasons) without any background on medical waste management. Those who are trained, received training from senior health center staff who themselves are not experts on medical waste management. They are no controlled services to evaluate those managing these wastes as no legal guide lines exist to that effect. Consequently, the application of poor medical waste management practices that endangers the life of health workers themselves, the public and the environment.

\subsection{Treatment and disposal of waste}

All of the healthcare facilities treated their own healthcare waste by self-made incinerators as shown in figure 6 (for syringes) and 7 (for all other solid waste). These incinerators were very rudimentary as they had poor design and operational problems, so not operating according to international best practices. The incinerators were not fitted with typical air pollution control devices, including cyclones, semi-dry scrubbers and bag house filters (or fabric dust removers). Moreover, the resulting ash was openly dumped outside near the incinerators as for figure 6 and remained at the bottom of brick constructed incinerator for figure 7 , contaminating ground water, especially low-lying areas subject to frequent flooding. None of the facilities had a specific procedure for the handling of this resulting ash and it was typically spread on land as case with figure 6 or disposed of in the open dumps as in figure7. Incineration or open burning of healthcare waste releases pollutants which are usually emitted either in condensed (particulate matter) or gaseous phases (Mmereki et al. 2017;Palenik and Cumberlander, 1993; Eggen and Moeder, 2010). Their chimneys were also short and, depending on wind direction, emitted gases that were dispersed to nearby communities, causing nuisance and being a potential cause of bronchitis and pulmonary ailments such as asthma (Al-Khatib A and Sato, 2009; Mmereki et al. 2017). There was no control of temperature during incineration although the different types of wastes required different burning temperatures. Unfortunately, waste that is improperly incinerated, especially containing plastic materials, is known to give rise to toxic gases such as dioxins and furans that are carcinogenic (Mmereki et al. 2017; Lee et al. 2002). However, in mission health centers the incineration was much handled with respect to pollution as shown in figure 8 with a device that permit easy collection of ash and a sealed roof. Here, after incineration, the ash was collected and landfilled. These problems are typical of any developing country that cannot afford to buy more environmentally friendly incinerators with the latest technology (Mmereki et al. 2017; Harhay et al. 2009).

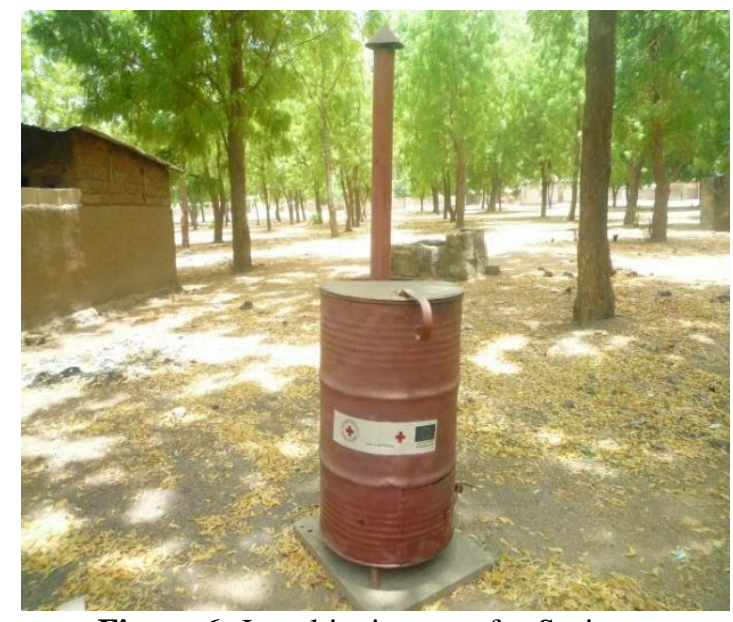

Figure 6: Local incinerator for Syringes 


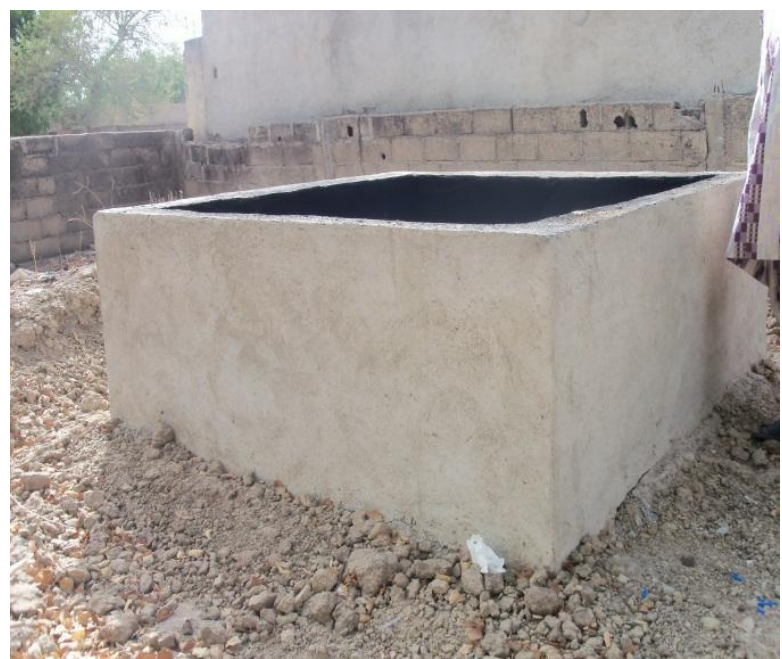

Figure 7: A brick constructed incinerator for other solid waste

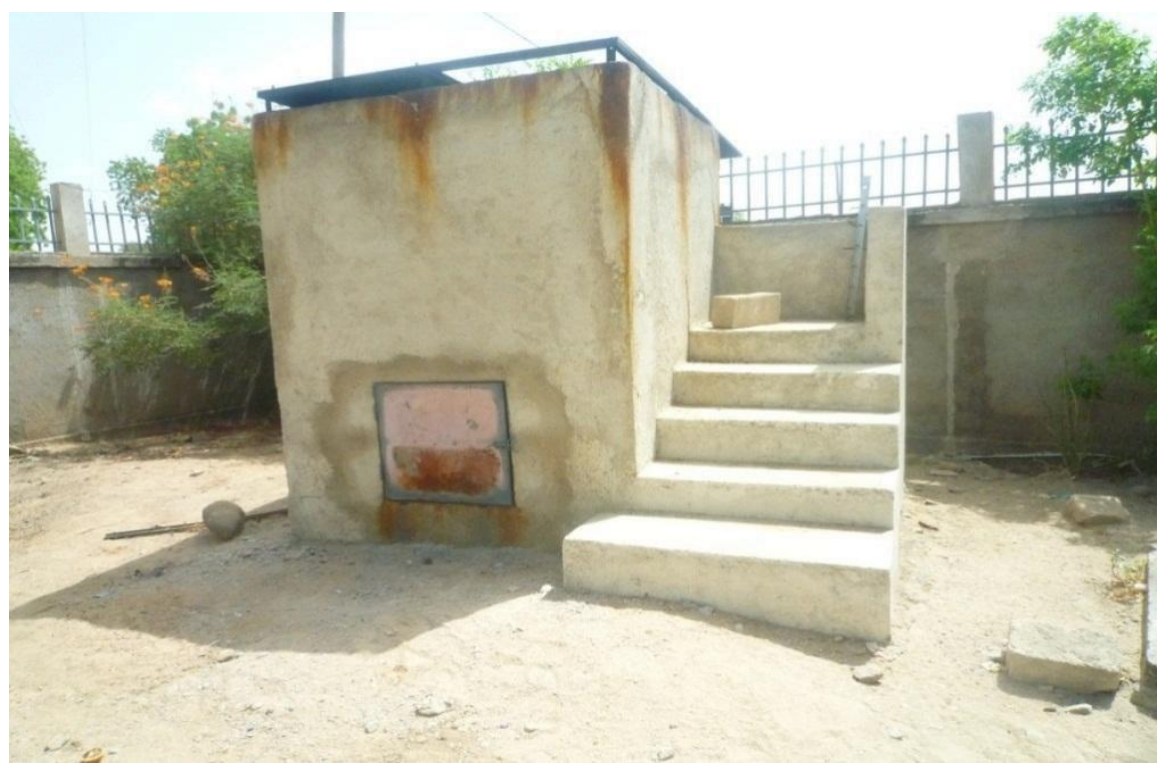

Figure 8: Incinerator for all types of waste

Solid accessories such as scissors, tubes and needles were disinfected by washing with tap water and then with chlorinated water (figure 9) and finally sterilized using a sterilizer (figure 10). Health centers without a modern sterilizer performed the sterilization by heating in pots provided for this purpose on a hot plate (figure 11). This was for the purpose of recycling. These sharps-like materials are generally known to be capable of transmitting diseases. Thus, safe handling and disposal of is an essential part of any infection control program (Mmereki et al. 2017; Jang et al. 2006). Thus, the need to extend the treatment of infectious waste to these sharps-like materials.

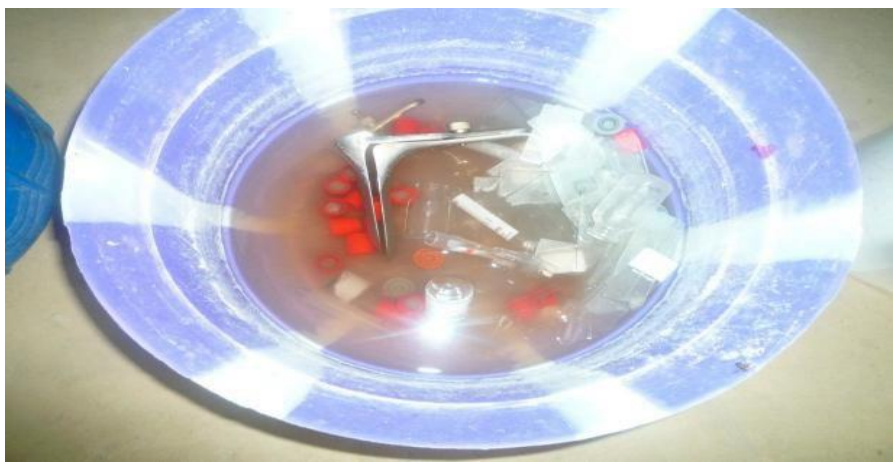

Figure 9: Disinfection of sharpmaterials 


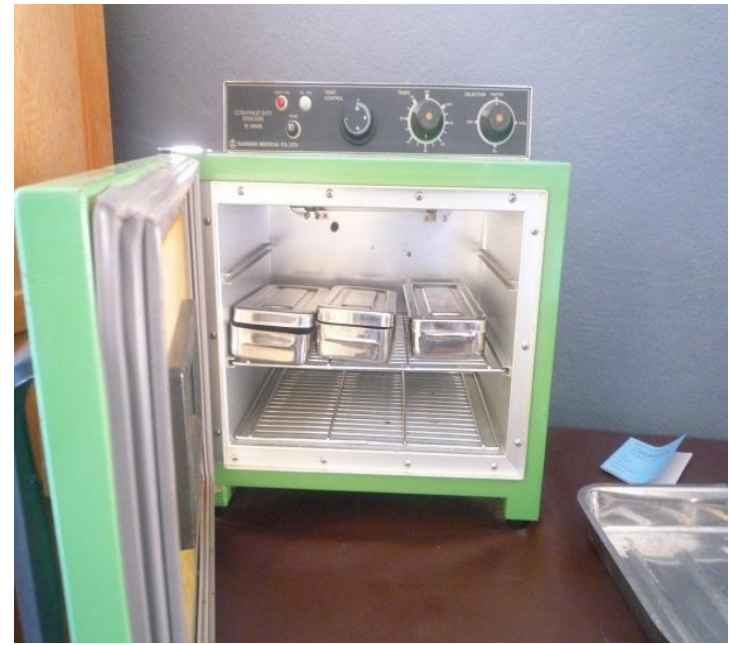

Figure 10: Modern disinfector

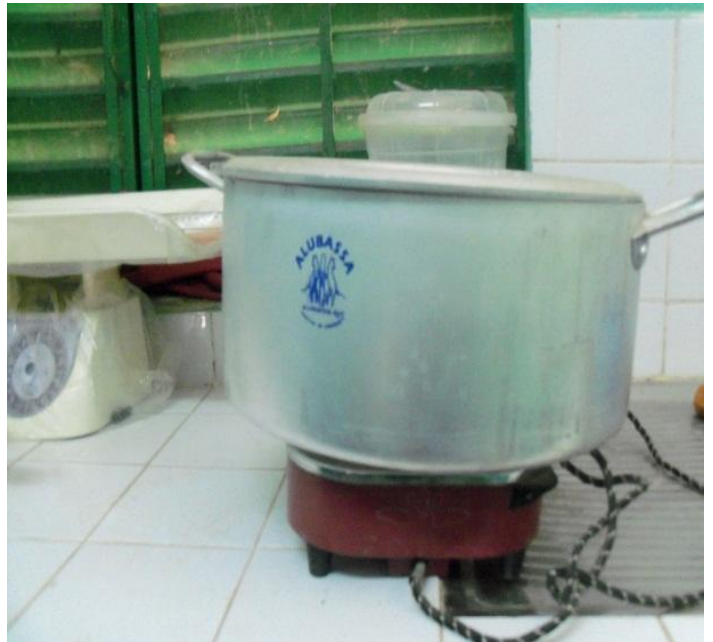

Figure 10: Disinfection of sharp materials in pots by boiling on heating plate

The most common methods of waste disposal were open dump and landfilling. Open dumping has long been recognized as a potential source of public health and environmental problems (Mmereki et al. 2017;Jang et al. 2006), because of its inherent problems such as leakage of toxic substances into the environment; easily accessed by insects, rodents and other small animals, most of which are disease vectors, has been replaced by landfilling in the management of solid wastes (Mmereki et al. 2017). Also, wind could easily blow over the dumped waste, dispersing air pollutants to nearby communities. The landfills were located at a distance away from the health facilities. The main idea of the landfill is storage and containment of the waste deposited into it (Mmereki et al. 2017; Mmereki et al. 2014]. However, how the landfills were operated in sharp contrast to normal procedures. It is important to mention that two of the health centres disposed their medical waste in nearby streams because of lack of space to construct waste handling facilities within their health centers. And considering that Maroua has a very hot climate, this is a potential source for human and environmental contamination as these streams are main water sources to most inhabitants especially for laundry and swimming. Tarikul Islam (2017) summarized the effects of the improper disposal of hospital waste to humans as well as the environment:

$>$ In warm temperature, sterile organic matter, like kitchen waste and pathological waste can become a potentially lethal source of toxic or disease-producing organisms.

$>$ The organic portion of medical waste also ferments and favors fly breeding.

$>$ The garbage in refuse attracts rats and the produced pathogen may be conveyed to human being through flies and dusts.

$>$ Contamination of drinking water by leachate entering an aquifer, surface water.

$>$ Burning of waste at low temperatures or in open container results in release of toxic pollutants (e.g. dioxin) in to the air. 
> Carcinogenic waste such as heavy metals, chemical solvents and preservatives pose serious human health risks not only to workers but to the general public as well.

$>$ Unprotected and insecure landfill may pose health hazard to the scavengers and inhabitants at the vicinity.

$>$ Pollutants from Medical waste (e.g. heavy metals and PCBs) are persistent in the environment.

$>$ With domestic animals being allowed to graze in open dumps, there is added risk of reintroducing pathogenic micro-organisms into the food chain.

$>$ Public nuisance (e.g. odors, scenic view, block the walkway, aesthetics, etc.).

$>$ Plastic bags, plastic containers, if not properly destroyed may contaminate the soil and also reduces the chance for water percolation into the soil during precipitation.

\subsection{Roles of Councils of Maroua and HYSACAM}

Our visit to the councils shows that they intervene in health centers waste management by offering waste bins to the different health centers. In Cameroon, the delivery of waste management services is a statutory duty for Municipal Councils (Manga et al., 2008; Tsamo, 2014). They are responsible for the provision and maintenance of infrastructure, e.g. waste disposal facilities; financing of all activities related to waste management; street sweeping, collection, transportation and disposal of household wastes as well as the management of all public spaces and infrastructure. These waste management related responsibilities are under the jurisdiction of the health and safety officers in the Hygiene and Sanitation Units of each Municipal Council. The highest qualified staff in each authority is the supervisor who may be a health worker. The Council has the responsibility for both creating and managing these units with partial responsibility for waste management or they may subcontract the responsibilities to third parties such as specialized waste management companies. In a recent study, Tsamo (2014) noticed that, not all the councils in Maroua have a health and sanitation service, and where it exist, have very few personnel, who do not fit the job profile. He also reported that, the Maroua urban council has partially subcontracted the management of waste in Maroua to a private company, HYSACAM. But the study at this company revealed that they collect and treat the waste without any distinction.

However, results of this study revealed that HYSACAM does not intervene in the management of hospital waste in Maroua. According to HYSACAM, these health centers mix their waste at the time of collection thus; handling it will expose HYSACAM employees to multiple health risks. This highlights the urgent need for proper education and improved legislation on medical waste management in Cameroon and Maroua in particularly.

\subsection{Assessment of regulations for hospital waste management in Cameroon}

It was revealed through our visit to the main structure responsible for the management of these hospitals at decentralized level, namely the Regional Delegation for the Public Health of the Far North, that they do not have any document concerning standard procedures on hospital waste discharge. As a result, each health center manager is encourage to take care of the management of this waste in "his or her own way". So we visited to the second structure responsible for conceiving and enforcing waste management legislation at decentralized level ,namely the Regional Delegation for the Environment, Nature Conservation and Sustainable Development. The head of the unit responsible for waste management revealed that there is a regulation in force concerning hospital waste in the world, but that there is no national law on medical waste management. Nevertheless, he revealed that a law that regulates the management of all waste exists in Cameroon and especially in the city of Maroua. As a result, this service also encourages each health center to take care of the waste it generates within it, either by setting up a commission or by appointing a person responsible for organizing waste management.

Although, waste management legislation has evolved in Cameroon with time especially within the past 10 years (Manga et al. 2008), the plethora of waste management related statutory instruments and regulations are often either incomplete (such as addressing different waste e.g. medical waste) and not enforced. This situation result from the fact that in Cameroon, several ministerial departments with conflicting roles and responsibilities have mandates to implement solid waste management regulations as the current regulatory system relies on a top-down approach to decision making wherein the ministerial departments are able to exercise control over local councils which have limited autonomy. This results in decisions that reflect political inclinations rather than scientific reality (Manga et al. 2008). This result in the rudimentary health centers waste management methods reported in this study as no health center has any legal constraints to obey whatever procedure. But this study did not investigate if there has been human or environmental contamination linked to poor management of waste in the health centers studied (we hope this is done sooner to better inform the government to make appropriate and enforceable rules). 


\section{Conclusion and Suggestions}

This study was aimed at identifying the different health centres in Maroua, evaluate their personnel awareness on medical waste, identify the different types of waste generated and the management practices used in this health centers. This because proper management of healthcare waste has become a major concern for solid waste professionals, managers, environmentalists, etc., because of the diversity in the composition of the waste stream and a presence of myriad of infectious and non-infectious materials as well as general waste within it. Unfortunately, in developing countries, little data is available concerning the management of medical waste. Although there was some awareness about medical waste risks and safe handling procedures among hospitals administrators, the level was very low as most waste management practices were defined by health centres themselves and not based on any obliged procedures. The local structures that should handle and control health centers waste are completely absent on the field as no legislation obliges them to do so. Practices such as sorting, collection, treatment and disposal were very rudimentary as most materials used for these processes were self-made; with possibility of human (staff and visitors) and environmental contamination linked to these processes.

From this study it can be concluded that there is an urgent need for raising awareness and education on medical waste issues in Maroua in particular and Cameroon at large. Proper waste management strategy is needed to ensure human health and environmental safety. This can be achieved through training of staff on solid waste management systems in different health centers; developing and harmonising national and local regulations and guidelines for health centers waste collection, separation, storage, transportation and disposal and empowering the local councils with qualified personnel, material and financial resources for control and construction of standard disposal facilities.

\section{Reference}

[1]. EL Mabrouk F A (2014), Medical Waste Management in LibyaNorth eastern Region Hospitals as a Case Study available at uob.edu.ly/assets/uploads/pagedownloads/885c5-209.pdf

Mmereki D; Baldwin A; Li B and Liu M (2017), Healthcare waste management in Botswana: storage, collection, treatment and disposal system, J Mater Cycles Waste Manag, 19:351-365 DOI 10.1007/s10163-015-0429-0

[2]. Oli AN; Ekejindu CC; Adje DU; Ezeobi I; Ejiofor OS; Ibeh CC and Ubajaka CF (2016), Healthcare waste management in selected government and private hospitals in Southeast Nigeria, Asian Pac J Trop Biomed, 6(1): 84-89 http://dx.doi.org/10.1016/j.apjtb.2015.09.019

[3]. WHO (2005a). Healthcare waste management. World Health Organization: www.healthcarewaste.org

[4]. Nascimento Silva AC; Andrade Mota EL; Alves Costa E and Galvão Reis M 2013, Wastes from Health-Care, Pathogenic Microorganisms, EnvironmentalFactors and Disinfection Processes: conceptual evolution andenvironmental education, Microbial pathogens and strategies for combating them: science, technology and education (A. Méndez-Vilas, Ed.) @ FORMATEX 2013

[5]. World Health Organization, 1999, Safe management of wastes from health-care activities, Genève.

[6]. Tiong CS; Latiff PA and Karuppannan S (2012), Medical Waste Management In Private Medical Clinics Taiping, Perak, International Conference on Ecological, Environmental and Bio-Sciences (ICEEBS'2012) April 13-15, Pattaya

[7]. Hadipour M; Saffarian S; Shafiee M and Tahmasebi S (2014), Measurement and management of hospital waste in southern Iran: a case study. J Mater Cycles Waste Manag, 16(4):747-752. doi:10.1007/s10163-013-0214-x

[8]. Shine E; Gombajav E; Nishimura A; Hamajima N and Ito K (2008), Health waste managementin the capital city of Mongolia, Waste Management 28, 435-444.

[9]. World Health Organization, WHO (2008), Healthcare waste and its safe management. Accessed online at http://www.healthcarewaste.org

[10]. Tudor TL; Noonan CL and Jenkin LET (2005), Healthcare waste management: a case study from the Cornwall NHS, UK. Waste Management, 25 (6), 606-615

[11]. National Institute of Statistics (2015), AnnualStatistics of Cameroon, 2015 edition, Chapter 4 : Characteristics of the Population

[12]. Mato RRAM and Kassenga ME (1999), Critical review of industrial and medical waste practices in Dar Salaam City. ResourConservRecycl, 25:271-287

[13]. Djao R; Brekmo k; Mahamat A, and Asanji AM (2011), Guide pratique de la gestion d'une épidémie de choléra, Ministère de la Santé Publique/SNV Cameroun.

[14]. WHO (2011), Lutte contre l'épidémie de choléra à Yaoundé et dans la région du centre. Bureau pays du Cameroun. Santé au quotidien No 66.

[15]. Sabour RM; Mohamedifard A and Kamalan H (2007), A mathematical model to predict the composition and generation of hospital wastes in Iran. Waste Manag, 27:584-587. doi:10.1016/j.wasman.2006.05.010

[16]. Mbongwe B; Mmereki BT and Magashula A (2008), Healthcare waste management: current practices in selected healthcare facilities in Botswana. Waste ManagResour 28:226-233

[17]. Oke A (2008), Management of immunization solid wastes in Kano State, Nigeria. Waste Manag, 28:2512-2521

[18]. Palenik C and Cumberlander ND (1993), Effects of steam sterilization on contents of sharp containers, Am J Infect Control, 21:2833

[19]. Eggen T and Moeder A (2010), Municipal landfill leachates: a significant source for new and emerging pollutants, Sci Total Environ, 408:5147-5157

[20]. Al-Khatib A and Sato C (2009), Solid health care waste management status at health care centers in the West Bank-Palestinian Territory. Waste Manag, 29:2398-2403

[21]. Lee KB; Ellenbecker MJ and Eraso RM (2002) Analyses of the recycling potential of medical plastic wastes, Waste Manag, 22:461-470

[22]. Harhay M; Halpern S; Harhay J and Olliaro P (2009), Health care waste management: a neglected and growing public health problem worldwide, Trop Med Int Health, 14(11):1414-1417 
[23]. Jang YC; Lee C; Yoon OS and Kim H (2006), Medical waste management in Korea, J Environ Manag, 80(2):107-115

[24]. Mmereki D, Li B, Meng L (2014), Hazardous and toxic waste management in Botswana: practices and challenges, Waste Manage Res, 32(12):1158-1168

[25]. Tarikul Islam Md (2017), Present Status of Medical Waste Disposal System in ChittagongMedical College Hospital (CMCH), Chittagong,IOSR Journal of Environmental Science, Toxicology and Food Technology (IOSR-JESTFT), Volume 11, Issue 2 Ver. I, PP 107-112

[26]. Manga VE; Forton OT and Read AD (2008), Waste management in Cameroon: A new policy perspective? Resources, Conservation and Recycling, 52: 592-600

[27]. Tsamo C (2014), E-waste Assessment in Cameroon. Case study: Town of Maroua, International Journal of ChemTech Research, Vol.6, No.1, pp 681-690 